\title{
EXPLAINING GOOD FAITH IN IRANIAN JURISPRUDENCE AND LAW
}

\author{
Akbar Bashiri ${ }^{1}$ \\ Mohsen Seifollahi ${ }^{2}$
}

\begin{abstract}
The principle of good faith is one of the most debated issues in legal circles. This principle has been accepted in the private law of various countries. On the other hand, this notion has also generated conversations and attracted proponents among Imami jurists. However, unfortunately law and jurisprudence of Iran lack a comprehensive and yet precise explanation of the former principle. In fact jurisprudence lacks any principle named as good faith and what jurists have referred to is close in meaning to good faith; while the Iranian law system's situation is no different either.
\end{abstract}

Keywords: Good faith, Jurisprudence, Iran.

\section{INTRODUCTION}

In general, as a tool for maintaining societal order and justice, law includes several leverages each of which corresponds to certain conditions of phenomena; these have been employed by various legal systems throughout the time. One of the most important of these leverages that has currently received several enforcement-related, scope-related and role-related debates in every legal system in the world is the principle of good faith. In a general division, this principle is divided into two aspects of supportive and obligatory. By the first aspect of good faith it is referred to absolute unawareness. In other words, in this aspect, good faith is attributed to a person who is unaware of a fact that has negative legal consequences. The result of unawareness of the person about the undesirable legal fact is defined as the support of law for the unaware person. This type of good faith is observed in rights of properties, in case of good faith of the receiver in the process of transfer of ownership; in family rights, in case of doubtful adultery; in rights of commercial documents and, in case of impossibility of imposing objections on the person with good faith. On the other hand, the obligatory aspect of good faith implies appropriate behavior and consideration for others' interests. This consideration can appear in both affirmative and negative aspects such as giving information and avoiding tendency. Nowadays, this aspect of good faith has become one of the most

\footnotetext{
1 Assistant Professor, Department of Law, Maragheh Branch, Islamic Azad University, Maragheh, Iran. E-mail: akbarbashri@yahoo.com
} 
important debates in every legal system whether domestic or international. This principle has been referred to in various important international documents including the international convention on sale of goods, the institute of equalization of private law and the principles of European contracts. However, since these documents are outside the scope of this study, they have been left out of discussions. The present paper merely elaborates on the subject of this principle in domestic Iranian law.

Principles including freedom of will, necessity of vindication, rule of will, prohibition of unfairness and etc. have gradually entered the era of law from the era of morality by the establishment of legal rules and jurisdictions (Ibrahimi, 2012: 75). This principle has extensive legal consequences in every legal system in the world, especially in the system of written rights. The necessity of studying this subject lies in the fact that nowadays, attitudes towards the rights of contracts and the corresponding ruling values have changed into a type of orientation towards the explicit acceptance of good faith by legal systems.

\section{LEXICAL DEFINITION OF GOOD FAITH}

The principle of good faith has been present in legal discussions since the era of ancient Greece and in terms of modern law, this principle became the destination of more and more orientations as France tried to expand its commercial relationships during the $16^{\text {th }}$ century. Good faith is composed of the words "Good" and "Faith" and in contracts; it has been associated to fair dealing. The dictionary of Dehkhoda puts ill-will as the antonym of good faith which lexically implies good will (Dehkhoda, 1997: 7867). In his book of legal terminology, Dr. J. Langroodi defines good faith as follows: the intellectual state of a person who mistakenly undertakes a legal action which is legal but not consistent with essence of law. In this case, the legislator has provided some extent of support for the unaware person against the harmful consequences of the action. As an instance, imagine someone who believes he/she has dealt with the real owner of a property and has received the property from that very real owner while he/she has dealt with a usurper instead (Jafari Langroodi, 1997:215).

In this context another lawyer has suggested that "good faith is close to rationality and common law" (Safaei, 2005: 47). However this definition has received various criticisms. First of all, nowadays good faith is a legal principle while common law is considered as an assignment principle and one can escape it. And second, good faith is permanent but common law is transient, variable and even sometimes wrong (Mohseni, 2006: 229).

\section{GOOD FAITH IN JURISPRUDENCE}

Iranian law has made several borrowings from Islamic Jurisprudence. In order to study this concept in

${ }^{2}$ PhD Student, Department of Law, Maragheh Branch, Islamic Azad University, Maragheh, Iran. E-mail: m.seifollahi@gmail.com vol.11, nº. 03, Rio de Janeiro, 2018. pp. 1787-1797 
jurisprudence, we will take a look at Islamic rules. Jurisprudence lacks any separate and specific principle named good faith. However, by following the unity of proof in other juridical principles, one can reach good faith. The following studies some of these principles:

\section{The principle of beneficence}

In Quran, god says lack of attending to charity is no fault for the disabled, the sick and the one with no affordability as long as they have good faith in God and his prophet. The people with goodwill will face no charge because god is merciful and compassionate (Quran, 2001, Sura of Taube, Verse 91). In addition, in another one of the verses it has been stated that there is no punishment for benefactors other than goodness (Quran, 2001, Sura of Al-Rahman, Verse 60). In these instances, honest behavior can be considered as one of the instances of good faith.

\section{The Principle of Fraud}

Lexically, fraud means deception and misleading. In addition, certain lawyers in their books have stated that it includes crimes related to deception in business; whether being in form of hiding the flaws of a property or stating advantages that do not exist in the property (Jafari Langroodi, 1997: 491; Qomi, 1921: 135). Nevertheless, in juridical terms, fraud in business has appeared in forms of hiding the flaws of a property or stating advantages that do not exist in the property. In addition, it is usually referred to as a specific type of deception which is the combining of an external object with the sold good (Najafi, 1993: 91). Fraud is somehow related to good faith and one instance of this relatedness is that in order for the fraud to be realized, there is a need for combination of the awareness of the deceiver and unawareness of the deceived. On this basis, fraud is true only when something has been kept from the customer. So in cases of conflicts in which nothing has been concealed, there is no fraud. The necessity of existence of the former awareness and unawareness for the realization of fraud implies that both actions and silence of people in their relationships must be consistent with the principles of good faith. The emphasis on the element of awareness of the deceiver guarantees the objection against the ill-will of the deceiver regarding the deceived while the emphasis on the element of unawareness of the deceived implies the supportive aspect of good faith according to which supporting an entity is subject to his/her unawareness about the fact (Haji Pour, 2013: 43).

\section{The Principle of No-Harm}

The principle of no-harm is in a tight relationship with the principle of good faith. In case of law, this 
principle is used in cases where a person uses his/her ownership right with an ill-will of harming another person(s) (Jafari Langroodi, 2007: 587). This principle is somehow related to the negative aspect of good faith. This principle has been in effect from the beginning of Islam and misusing rights has been consistently prohibited throughout the history of Islam. One instance can be dealing with the aim of escaping the religion. This instance is a case of misuse of right and according to the principle of no-harm it is prohibited.

\section{Doubtful Adultery}

Doubtful adultery is either due to a subjective mistake, such as having intercourse with an alien who the man thinks is his wife; or due to a sentence fault, such as a man marrying the sister of a man who he used to have sodomy with and having intercourse with the wife while thinking that their marriage is valid.

Doubtful adultery does not result in confirmation of adultery; however, it results in confirmation and proof of children and Idda for the wife. In case of doubtful adultery, if the woman is aware of the invalidity of the intercourse, there would be no dowry for the woman. There exist disagreements regarding the confirmation of alimony of the woman in case of pregnancy after doubtful adultery. In general, doubtful adultery raises the same sanctities as the valid marriage and results in sanctity of the mother, daughter and the girl grandchild of the woman for the man as well as the sanctity of father, son and boy grandchild of the man for the woman. However, this sentence assumes that intercourse has taken place before marrying either of the named; otherwise no sanctity would be raised.

\section{GOOD FAITH IN LAW}

\section{Good faith in constitution}

The very first instance of good faith can be found in the article 40 of Iranian Constitution. However, some believe that this article refers to ill-will and not good faith. Nevertheless, even if it is true, the notion of ill-will is the direct antonym of good faith and therefore, this article does refer to good faith. The former article maintains that "nobody con use his/her rights as a tool for harming others or violating public interests" (Rah Paik, 2003: 68)

\section{Good faith in the law of commerce}

The article 154 of the law of commerce (1922) maintains: one cannot give subscription to an associate with limited responsibility, unless it does not result in the deduction of his/her capital. If as the result of occurred harms, a deduction was made from the partner's share of the associate with limited responsibility; further payment 
of any benefits to him/her would be banned until the shortage is compensated. Whenever a fee is paid regardless of the upper law, the associate with limited responsibility would be responsible for the commitments of the company to a certain extent corresponding to the amount of received fee unless the associate has received the fee with good faith in the credibility of the balance sheet.

In the context of the law of commerce, the issue of commercial documents involves the principle of sustaining of objections or in other words, the principle of irrefutability of objections. This principle implies that whenever a commercial document is put into effect and several responsible parties emerge as a result, their objections regarding the good-faith person would all be denied and no one can cite them. This principle favors the good-faith possessor of the commercial document against the parties responsible for and committed to the document (Sokooti, 2016: 117). Therefore, whenever the buyer in a sale contract or the tenant of a property issue a commercial document and place the document in the possession of the seller or the landlord and the document is then transferred to third parties with writing on the back of the document, when the possessor of the document refers to the issuer and demands the fee mentioned by the document, the issuer cannot avoid paying the fee by posing the objection that the business document has been voided or that the seller has not fulfilled his obligations in the delivery of the good. This is because according to the principle of irrefutability of objections against the person with good faith, the issuer will not have the right to object the good faith possessor of the commercial document.

According to the upper content, certain lawyers believe that this principle is also evident in the articles 230,231, 249 and, 307 of the law of commerce. However, the prerequisite for citation of the former principle is the existence of good-faith in the possessor of the commercial document. In other words, this principle supports the possessor with good-faith (Barikloo, 2012: 61).

\section{Good Faith in the Law of Civil Responsibility}

The article 8 of the law of civil responsibility (1960) not only accepts the principle of good faith in Iranian law, but also maintains that what in Iranian law is referred to by the words of awareness and unawareness is the same as what modern law refers to by the phrases of ill-will and good faith. This article states: the one who poses harm to the situation, credibility and respectability of another person through giving false approvals or giving information that are not true, he/she will be responsible for compensation of the occurred harms. When someone loses costumers as a result of misinformation spread by another person, the harmed can ask for the compensation of imposed harms and losses. The former principle has been left out of the consideration of most lawyers while it refers to both material and spiritual losses that someone may suffer due to the negligence of another. However this 
article generally deals with material damages instead of spiritual ones. Nevertheless, there is no doubt in the necessity of compensation for spiritual losses but there exist differences between the views of lawyers regarding the qualities of compensation for spiritual damages. In this article, good faith is the boundary of proving the occurrence of harm in a way that if the harm doer has done the act out of good faith, he/she would face no charges; however in case of lack of good faith, the harm doer would be sentenced to compensation for damages (Safaei, 2014: 78\&152).

\section{Good Faith in the Law of Electronic Commerce}

According to the article 3 of the law of e-commerce (1993), while interpreting this law one must pay attention to the international characteristics, the necessity of further development of coordination between countries in its application, and the necessity of adherence to good faith. On the other hand, the article 35 of the same law maintains that information that are given to customers must be clear and explicit and must be communicated to the customer at the appropriate time and through proper communicational instruments based on the necessity of good faith in deals while considering for people with disabilities and children. E-commerce includes commerce, business and, sales and purchases of goods and services through electronic instruments and tools based on remote communications. In this context, the legislator has put extra emphasis on the necessity of adherence to good faith. It seems that not many references have been made to this principle at the time of contract; however the unity of proof of this affair at the time of contract can be used for spreading the principle to the contracting phase too.

\section{Good Faith in Patent Law}

In the law of patent, industrial designs and, trademarks and brands (2007), good faith has been viewed as a principle. In this regard, the $S 4$ of article 15 states exploitation by a person of good faith prior to the application for patent or before the date of application for priority of patent, when the person has been using the invention or has been undertaking serious actions to get prepared for using the invention in Iran is not objectionable.

\section{Good Faith in Insurance Law}

Providing the client with a questionnaire for collection of true data regarding the subject of insurance contract has become a certain custom of insurance both in Iran and other countries of the world. No one can any longer imagine insurance contracts without questionnaires being filled. In French law this questionnaire has been known as "le systeme la declaration spontanee". In these cases the information given by the insurer can result in 
increase of insurance fee or even it can make the client cancel the insurance contract. If in this cases it is proved that in-spite of being aware of the importance of issue that was not disclosed, the insurer has avoided stating the issue, and French law considers the insurer responsible because of lack of adherence to good faith.

Since in Iranian law the limits of good-faith have not been determined, it cannot be considered as the criterion of responsibility in case of proving the awareness of insurer about the undisclosed risk of the contract. However, the following instances in the law of insurance have considered good faith as a principle.

According to the article 11 of the insurance law, if client states the price of a property exaggeratedly with the intention of undertaking a financial fraud, the insurance contract would be voided and the paid insurance fee would not be returned. On the other hand, article 12 of this law states that whenever the client intentionally avoids stating an issue or intentionally gives false information and the result of not disclosing the issue or giving misinformation is a change in the subject of risk or the declination of the importance of risk in the view of insurer, the insurance contract would be voided, even if the aforementioned acts have no effect on the occurrence of incident. In this case, not only the insurance fees paid by the client would not be returned, but also the insurer can demand for the past due insurance installments.

\section{Good Faith in Legal Precedents}

Good faith has been explicitly referred to in legal precedents related to commercial documents. For example, in a case held in 1994, the defendant claimed that the citable check related to the dispute was in the possession of a person named Gholam-Hussein Amanat to whom he had no debt. The court rejected the claim and reasoned: the objection is not accepted since first of all, the possessor of the check related to the main plea is someone other than the Gholam-Hussein Amanat. And therefore, the relationship between the plaintiff and the defendant is due to commercial documents and in these cases, commercial documents are not subjected to any objections. One cannot pose objections against people of good-faith. Therefore, the article 249 of the law of commerce, maintains that the issuer is responsible unconditionally. In addition, from the point of view of principles governing commercial documents, the prerequisite for maintenance of credibility of the commercial document is being immune to any objections (however, in case of the mentioned case, the objections are citable in case of the relationship between the issuer of the check and the primary possessor; however in this case there was no dispute between the issuer of the check and the primary possessor and therefore the court count not enter the area of credibility or lack of credibility of objections) (Sokooti, 130).

\section{Good Faith in Pre-Contract}


Adherence to this principle during the pre-contract time requires the both parties to be in complete honest cooperation with each other in order to obtain their mutual goals. In addition, they should consider for each other's benefits while also maintaining confidentiality regarding classified information (Barikloo, 2012: 66).

\section{COMMITMENT TO PROVIDE INFORMATION}

A certain prerequisite of good faith is informing during the pre-contract time. The parties of the contract must be informed of the preliminary discussions regarding the principal elements of the contract that would be effective on the decisions they make. They also should be aware of each other's conditions and the characteristics of these conditions (Barikloo, 2012: 66). Giving information during the pre-contract time, results in the further sustainability and security of contracts (Kessler, 1964: 401). In fact if the parties hold a contract and after sometime one of the parties finds out that he/she had not been made aware of certain information that would influence his/her previously made decisions, this could be considered as the termination of contract and therefore the sustainability of the contract would be endangered.

\section{COMMITMENT TO SERIOUSNESS}

In general, the start of preliminary discussions states that the parties are serious regarding the contract and seeking to obtain contract-based relationships. Here, it is generally and principally believed that no seller would enter a discussion with another party without an intention of selling and vice versa (Taleb Ahmadi, 2010: 115). Seriousness in the pre-contract time is based on the principle of good faith and is defined as having the intention of making progress in preliminary discussions. If it is proved that either of the sides of the contract had not been serious for the final contract, the party would be responsible towards the other.

\section{COMMITMENT TO CLARITY}

Irrespective of the phase of preliminary discussions, it is necessary to have a clear and non-ambiguous interaction and it has been stated in the law of many countries. Nevertheless, in Iranian law, lack of clarity during the pre-contract time can result in misunderstandings and can trouble the parties with reaching a real agreement. If it is proved that no agreement has been reached due to lack of clarity during the preliminary discussions, the contract would be voided and will lose its effect. 


\section{COMMITMENT TO SECRECY}

The information disclosed by the parties must be guaranteed to be kept secret from others due to the principle of good faith. This is the same as secrecy obligation.

\section{LACK OF PARALLEL NEGOTIATION}

Lawyers hold different views regarding this issue. Some lawyers believe that parallel negotiation in preliminary conversations is in conflict with the principle of good faith in the period of pre-contract and causes responsibility. On the contrary, other lawyers believe that considering the competitiveness of the market and the need for freedom except in cases of exclusive negotiations, simultaneous negotiations with several parties will not raise any responsibilities (Ansari, 2009: 196).

\section{CONCLUSIONS}

Rules and regulations of various legal systems reveal that the mutual concern between every legal system is to support good faith in legal relationships while confronting ill-will. In terms of definition, good faith is defined as consideration for others' interests and it is gradually beginning to find its place in legal systems in a way that even countries that have been traditionally opposed general notions such as good faith are somehow moving towards the acceptance of some sort of good faith. Since Iranian civil law lacks the notion of good faith, some lawyers in Iran have not accepted this principle. This is while some other lawyers have tried to make citations to instances within the civil code in order to show that the principle exists. However, in more recent laws including the patent law and electronic commerce law, the notion of good faith is evident and referable. This leads us to the conclusion that Iranian legislator has accepted the concept of good faith and that we should not neglect this concept merely by stating that our civil code lacks any direct references to it. In fact, this is a principle in Iranian law and although that it may initially look difficult, good faith has been accepted by the Iranian Legislator. Good faith is an extensive concept and with respect to each of its meanings it adopts a different role as well. Among these meanings, there were some definitions that were found to be the most important ones. These included good faith as equal to honesty, good faith as equal to honest cooperation and commitment to cooperation and etc. although that Iranian law has not explicitly referred to good faith; it has considered good faith in positive and negative forms. In addition, in pre-contract commitments based on disclosure of information, dealing with good faith has been more or less considered by lawyers and scholars. These provide the necessary contexts for the acceptance of this principle. In its essential definition, good faith has a supportive role and by referring to it the law can support the 
unaware person with good faith. In such circumstances it is assumed that the action is not legally obstructed. In other words, good faith makes the person immune to responsibilities. This is while in terms of issues including honesty and trusteeship, good faith will not have any supportive aspects and would be considered as an obligatory principle and raises various responsibilities.

\section{EXPLICANDO A BOA FÉ NA JURISPRUDENCIA E LEI IRANIANA}

\section{Resumo}

O princípio da boa fé é uma das questões mais debatidas nos círculos jurídicos. Este princípio foi aceito no direito privado de vários países. Por outro lado, essa noção também gerou conversas e atraiu proponentes entre os juristas do Imami. No entanto, infelizmente, a lei e a jurisprudência do Irã carecem de uma explicação abrangente e ainda precisa do princípio anterior. $\mathrm{Na}$ verdade, a jurisprudência carece de qualquer princípio chamado de boa fé e aquilo a que os juristas se referem é de significado próximo à boa fé; ao mesmo tempo, a situação do sistema de leis iranianas também não é diferente.

Palavras-chave: Boa fé, jurisprudência, Irã.

\section{REFERENCES}

IMAMI, Seyyed Hassan, Civil Rights, Volumes 1 to 3, Imprint, Islamiya Bookstore, 1973.

ANSARI, Ali, Goodwill Theory, Jungle Publications, 2009.

BARIK LEO, Alireza; Seyyed Ali Khazaie, Principle of Goodwill and its Consequences in Pre-Contract Period with a Comparative Study in the Laws of England and France, Legal District of Justice, 2011.

JAFARI LANGROUDI, Mohammad Jafar, Expanded in the Law of Terminology, Vol. 2, Third Edition, Tehran, Ganj Danesh, 2007.

HAJIPOUR, Morteza, Comparative Study of the Goodwill Principle in Contract Law, Doctoral dissertation, University of Law and Political Science, Tehran University, 2009.

KHAZAEE, Hasan, Trade Law, Volume 3, First Edition, Publication of Law, 2006.

DILAMI, Ahmad, Goodwill on Civil Responsibility, Publishing Rate, Tehran, 2010.

DEHKHODA, Ali Akbar, Dictionary, Vol. 6, Tehran University Press, 1997.

RAH PEYK, Siamak, Prohibition of Right Abuse, Islamic Studies Magazine, No. 62, 2003. 
SOTOUDEH TEHRANI, Hassan (1995), Trade Law, Volume 3, Publishing Dagestar, Tehran.

SOKOTTI NASIMI, Reza; Analytical Issues of Trade Documents Rights, Second Edition, Majd Publications, Tehran, 12016

ADEL MOSTAFA, Civil Rights, Taha Publishing, Tehran, 1999.

SAFAEI, Seyed Hossein, Introductory Course, Civil Rights, Commitments and Contracts, Volume II, Tehran, 2005.

KATOOZIAN, Naser, General Contracts, Vol. 3, Second Edition, Tehran, Publishing Co., 1997.

KAVIANI, Kourosh, Trademark Rights, Second Edition, Publishing Rate, Tehran, 2008.

MOHAGHEGH DAMAD, Mostafa, The rules of jurisprudence, Fourth edition, Tehran, 1983.

MUSAVI BAHRANI, Seyed Hassan, The role of good faith in contracts and contracts in jurisprudence and law, Journal of Political Science and Law, Tarbiat Moallem University, 1996.

NAJAFI KHANSARI, Moses, Minneh al-Taleb, vol. 2, Maktabe Al-Madei Publishing.

NOURI, Mohammad Ali; Electronic Trade Law, Ganj Danesh Library, Tehran, 2003.

KESLER, friedrich, fine edith, Culpa in Contrahendo, bargaining in good faith and freedom of contract: a comparative study, 77 harward law review, 1963-64.

Trabalho enviado em 12 de abril de 2018.

Aceito em 24 de maio de 2018. 